\title{
JPEB
}

Jurnal Penelitian Ekonomi dan Bisnis, 1 (1), 2016, Hal: 33 - 46

http://www.jpeb.dinus.ac.id

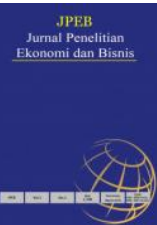

\section{PENGARUH INFORMASI AKUNTANSI DAN NON AKUNTANSI TERHADAP UNDERPRICING KETIKA INITIAL PUBLIC OFFERING DI BURSA EFEK INDONESIA}

\author{
Saifudin ${ }^{1 *}$ dan Dia Rahmawati ${ }^{2}$ \\ 1,2 Program Studi Akuntansi, Fakultas Ekonomi, Universitas Semarang \\ Jalan Soekarno- Hatta Tlogosari, Semarang 50196, Indonesia \\ *Corresponding Author : saifudin@usm.ac.id
}

Diterima: November 2015; Direvisi: Januari 2016; Dipublikasikan: Maret 2016

\begin{abstract}
This research is aimed to determine and to analyze the effect of accounting information variables that consist of Return on Equity (ROE), Debt Equity Ratio (DER), the amount of the company (size), Earning per Share (EPS) and non accounting information variables that consist of underwriter reputation, auditors reputation, firm age and inflation. Sample in this research is a go public companies doing initial public offering listed in Indonesia Stock Exchange (IDX) of 2009-2013. Data was collected by purposive sampling method. The analysis method that is used multiple linear regression analysis. The sample of this research is 75 companies. The results of this research showed that Debt Equity Ratio (DER), underwriter reputation, auditor's reputasion, age of firm, and inflation significant effect on underpricing. While Return On Equity (ROE), Earning Per Share (EPS), age of firm, the amount of the company (size) and inflation didn't significantly effect on underpricing.
\end{abstract}

Keywords: IPO; Underpricing; Financial Information Variable; Non Financial Information Variable.

ABSTRAK

Penelitian ini bertujuan untuk memperoleh bukti empiris tentang pengaruh informasi akuntansi yang terdiri dari ROE, DER, ukuran perusahaan (size), dan EPS dan non akuntansi yaitu reputasi underwriter, reputasi auditor, umur perusahaan, dan inflasi terhadap underpricing. Sampel dalam penelitian ini adalah semua perusahaan go public yang melakukan Initial Public Offering yang terdaftar di Bursa efek Indonesia (BEI) pada 2009-2013. Data yang dikumpulkan dengan metode purposive sampling.Penelitian dilakukan dengan menggunakan analisis regresi linear berganda. Sampel dalam penelitian ini sebanyak 75 perusahaan. Hasil penelitian ini menunjukkan Debt Equity Ratio (DER), reputasi underwriter, reputasi auditor, umur perusahaan dan inflasi berpengaruh signifikan terhadap underpricing. Sedangkan Return On Equity (ROE), Earning Per Share (EPS), Umur Perusahaan, Ukuran Perusahaan (Size) dan Inflasi tidak berpengaruh pada underpricing.

Kata Kunci: IPO; Underpricing; Informasi Akuntansi; Informasi Non Akuntansi 


\section{PENDAHULUAN}

Semakin berkembangnya suatu perusahaan, tentunya kebutuhan modal juga semakin meningkat. Kebutuhan modal tersebut, menyebabkan perusahaan melakukan beberapa alternatif pilihan untuk sumber pendanaannya. Sumber pendanaan bisa ditingkatkan dengan dukungan informasi akuntansi dan informasi non akuntansi. Informasi Akuntansi, merupakan infomasi yang didapatkan dari proses penyusunan laporan finansial. Sedangkan Informasi Non Akuntansi, adalah informasi yang didapatkan tidak dari laporan finansial. Informasi akuntansi yang terdiri dari ROE, DER, ukuran perusahaan (size), dan EPS dan non akuntansi yaitu reputasi underwriter, reputasi auditor, umur perusahaan, dan inflasi.

Perusahaan biasanya akan menggunakan laba ditahan sebagai alternatif pendanaan yang berasal dari dalam perusahaan, atau menggunakan alternatif lain diluar perusahaannya berupa hutang yang berasal dari kreditur, menerbitkan surat hutang atau obligasi, atau penerbitan saham baru (Jogiyanto, 2010). Hal yang paling umum dilakukan untuk mendapatkan dana perusahaan adalah dengan menjual sahamnya kepada masyarakat umum melalui bursa efek. Penawaran saham perusahaan kepada masyarakat melalui bursa efek ini sering disebut proses go public.

Go public merupakan alternatif terbaik untuk mempertahankan kelangsungan perusahaan dan meningkatkan skala perusahaan. Hal ini terbukti dengan meningkatnya perusahaan yang melakukan IPO dalam kurun waktu 10 tahun terakhir (2002-2011) meskipun krisis tengah terjadi dipasar saham global akibat krisis utang negara kawasan euro. (sp.beritasatu.com, 2011).Terdapat berbagai macam alasan mengapa perusahaan ingin go public dan menjual sahamnya kepada masyarakat umum, diantaranya untuk memperbaiki struktur modal, meningkatkan kapasitas produksi, memperluas pemasaran, memperluas hubungan bisnis dan meningkatkan kualitas manajemen (Samsul, 2006 dalam Ratnasari dan Gunasti, 2013). Proses awal go public adalah melakukan penawaran saham perdana kepada masyarakat melalui pasar perdana yang dikenal dengan istilah Initial Public Offering (IPO).

Harga saham yang dijual pada saat IPO ditentukan oleh kesepakatan antara emiten (perusahaan penerbit) dengan underwriter (penjamin emisi), sedangkan harga saham yang dijual pada pasar sekunder ditentukan oleh mekanisme pasar, yaitu permintaan dan penawaran. Penentuan harga saham pada saat IPO merupakan faktor penting, baik bagi emiten maupun underwriter karena berkaitan dengan jumlah dana yang akan diperoleh emiten dan risiko yang akan ditanggung oleh underwriter. Karena adanya perbedaan kepentingan antara emiten dengan underwriter ini menyebabkan perbedaan harga saham ketika diperdagangkan di bursa efek.Apabilaharga saat IPO lebih rendah dibandingkan dengan harga yang terjadi di pasar sekunder pada hari pertama, maka akan terjadi underpricing.(Jogiyanto, 2010).

Underpricing adalah adanya selisih positif antara harga saham di pasar sekunder dengan hargasahamdi pasar perdana atau saat IPO (Yolana dan Martani,2005).Fenomena underpricing terjadi karena adanya mispriced di pasar perdana sebagaiakibat adanya ketidakseimbangan informasi antara pihak underwriter denganpihak perusahaan. Salah satuyang menjadi polemik adalah kasus pada perusahaan milik BUMN yaitu PT. Krakatau Steelyang diharapkan pada saat Initial Public Offering, saham yang diperdagangkan dapat memberikan profit yang besar bagi kemajuan perusahaan karena memiliki performa cukup baik di Indonesia. Namun kenyataannya masih tetap mengalami underpricing.PT. Krakatau steel IPO dengan melepas sahamnya seharga Rp. 850 per saham yang dalam waktu singkat naik menjadi Rp. 1.270. IPO pada PT. Krakatau Steel dinilai tidak transparan danakuntabel, baik saat penetapan harga saham maupun penjatahan kuota saham.Harga saham IPO PT. Krakatau Steel dianggap terlalu murah sehingga menimbulkan kerugian bagi negara (Kompas.com 2010). 
Saifudin dan Dia Rahmawati: Pengaruh Informasi Akuntansi Dan Non Akuntansi Terhadap Underpricing Ketika Initial Public Offering Di Bursa Efek Indonesia

Dari kasus tersebut kita dapat mengetahui bahwa fenomena underpricing sering terjadi pada perusahaan yang melakukan IPO.Untuk meminimalisir terjadinya underpricing, informasi non akuntansi juga sangat penting untuk perusahaan yang akan melakukan go public. Kondisi underpricing sangat merugikan perusahaan karena dana yang diperoleh tidak maksimum.

Ratnasari dan Gunasti melakukan penelitian pada perusahaan yang IPO di BEI (20062011) dengan menguji variabel ROE, financial leverage, reputasi KAP, reputasi penanggung, dan inflasi menyatakan bahwa ROE, reputasi KAP dan reputasi penanggung memiliki dampak yang signifikan terhadap underpricing dengan tingkat 5\% sedangkan variabel financial leverage dan inflasi tidak berpengaruh terhadap underpricing. Sedangkan Aini (2013) yang melakukan penelitian yang sama pada perusahaan yang melakukan IPO di BEI (2007-2011) dengan menguji variabel DER, ROE, reputasi auditor, reputasi underwriter, ukuran perusahaan dan umur perusahaan dengan metode kuantitatif kausal menyatakan bahwa hanya variabel reputasi auditor yang berpengaruh terhadap underpricing, sedangkan variabel yang lainnya tidak berpengaruh. Variabel reputasi auditor dengan underpricing mempunyai hubungan negatif, yang artinya perusahaan IPO yang menggunakan auditor bereputasi tinggi maka akan menyebabkan tingkat underpricing yang rendah. Retnowati (2013) melakukan penelitian pada perusahaan yang IPO di BEI (2008-2011) dengan menggunakan variabel EPS, DER, ROA, ukuran perusahaan, prosentase penawaran saham dan umur perusahaan menyatakan bahwa DER, ROA, dan umur perusahaan tidak berpengaruh terhadap underpricing, sedangkan variabel EPS, ukuran Perusahaan dan prosentase penawaran saham mempunyai pengaruh yang signifikan terhadap underpricing.

Penelitian ini merupakan replikasi dari penelitian - penelitian sebelumnya terutama penelitian dari Ratnasari dan Gunasti (2013), Aini (2013) dan Retnowati (2013) denganmenambah variabel Ukuran Perusahaan (Size), EPS, dan Umur Perusahaan (Age) dan menggunakan return 15 hari setelah IPO. Penambahan variabel dilakukan karena Ratnasari dan Gunasti (2003) menduga faktor lain yang mempengaruhi underpricing sebesar 82,6 \% dalam penelitiannya adalah variabel ukuran perusahaan (size), EPS (Earning Per Share), dan umur perusahaan (age). Penggunaan return 15 hari setelah IPO digunakan untuk mendapatkan informasi lebih mengenai kinerja saham perusahaan dalam jangka panjang. Selain untuk menilai kinerja saham perusahaan penggunaan return 15 hari setelah IPO dilakukan karena adanya keterbatasan penelitian dari Ratnasari dan Gunasti (2013) yang mengatakan bahwa tidak signifikannya variabel tingkat inflasi terjadi karena penentuan harga closing price sehari setelah IPO sehingga antara harga offering dan closing masih dalam satu angka inflasi.

Menurut Wolk, et al. (2001) teori sinyal menjelaskan alasan perusahaan menyajikan informasi untuk pasar modal. Teori sinyal menunjukkan adanya asimetri informasi antara manajemen perusahaan dan pihak-pihak yang berkepentingan dengan informasi tersebut. Teori sinyal mengemukakan tentang bagaimana seharusnya perusahaan memberikan sinyal-sinyal pada pengguna laporan keuangan. Sedangkan menurut Jama'an (2008), signaling Theory mengemukakan tentang bagaimana seharusnya sebuah perusahaan memberikan sinyal kepada pengguna laporan keuangan. Sinyal ini berupa informasi mengenai apa yang sudah dilakukan oleh manajemen untuk merealisasikan keinginan pemilik. Sinyal dapat berupa promosi atau informasi lain yang menyatakan bahwa perusahaan tersebut lebih baik daripada perusahaan lain.

Teori sinyal menjelaskan bahwa pemberian sinyal dilakukan oleh manajer untuk mengurangi asimetri informasi. Manajer memberikan informasi melalui laporan keuangan bahwa mereka menerapkan kebijakan akuntansi konservatisme yang menghasilkan laba yang lebih berkualitas karena prinsip ini mencegah perusahaan melakukan tindakan membesar-besarkan 
laba dan membantu pengguna laporan keuangan dengan menyajikan laba dan aktiva yang tidak overstate.

\section{TINJAUAN PUSTAKA}

\section{Pengaruh Reputasi Underwriter terhadap Underpricing}

Sulistio (2005) dalam Aini (2013) menyatakan bahwa underwriter yang bereputasi tinggi lebih berpengalaman dan lebih profesional dalam menangani IPO perusahaan. Menurut Hartono (2005) dalam Aini (2013) reputasi underwriter yang baik akan memberikan sinyal yang baik pula pada pasar dan sebaliknya. Sebab pasar relatif mengenal underwriter yang bereputasi baik, dan pasar percaya bahwa underwriter dengan reputasi baik tidak akan menjamin perusahaan yang berkualitas rendah. Sehingga semakin tinggi reputasi underwriter maka mencerminkan resiko perusahaan IPO tersebut rendah serta rendah pula tingkat ketidakpastian saham dimasa mendatang, sehingga tingkat underpricingnya pun juga rendah (Suyatmin, 2006 dalam Aini, 2013).Penelitian Trisnaningsih (2005) dan Sandhiaji (2004) dalam Aini (2013) menyatakan bahwa variabel reputasi underwriter berpengaruh signifikan terhadap underpricing.Maka diambil hipotesis sebagai berikut :

H1 : Diduga Reputasi Underwriter berpengaruh terhadap Underpricing.

\section{Pengaruh Reputasi Auditor terhadap Underpricing.}

Reputasi auditor sangat berpengaruh terhadap kredibilitas laporan keuangan ketika perusahaan melakukan IPO.Informasi yang ada dalam prospectus, tingkat kepercayaannya tergantung dari pihak auditor yang melakukan audit. Semakin tinggi reputasi auditor maka semakin baik tingkat kepercayaan informasi yang ada dalam prospektus (Hartono, 2005 dalam Aini, 2013 ). Selain itu auditor yang profesional dan berkualitas akan mengurangi kesempatan emiten untuk berlaku curang dalam menyajikan informasi yang tidak menyesatkan mengenai prospeknya di masa mendatang. Untuk itulah laporan keuangan yang reputasinya baik akan lebih dipercaya oleh investor dibandingkan dengan yang tidak memiliki reputasi baik. Hal ini berarti auditor yang memiliki reputasi tinggi akan mengurangi ketidakpastian IPO serta mencerminkan resiko perusahaan IPO tersebut rendah, serta rendah pula tingkat underpricingnya. Penelitian Suyatmin (2006) dalah Aini (2013) menyatakan bahwa reputasi auditor berpengaruh signifikan terhadap underpricing. Maka diambil hipotesis sebagai berikut :

H2 : Diduga Reputasi Auditor berpengaruh terhadap Underpricing.

\section{Pengaruh Umur Perusahaan terhadap Underpricing}

Perusahaan yang telah lama berdiri bisa dipersepsikan sebagai perusahaan yang sudah tahan uji sehingga kadar resikonya rendah dan hal ini bisa menarik investor karena diyakini perusahaan yang sudah lama berdiri bisa dikatakan lebih berpengalaman dalam menghasilkan return bagi perusahaan yang pada akhirnya berdampak pada meningkatnya return yang diterima oleh investor dalam jangka panjang. Sehingga perusahaan yang telah lama berdiri akan mengurangi tingkat underpricing (Suyatmin, 2006 dalam Aini, 2013). Penelitian Sandhiaji (2004) dalam Aini (2013) menyatakan bahwa variabel umur perusahaan memiliki pengaruh yang signifikan terhadap underpricing. Maka diambil hipotesis sebagai berikut :

H3 : Diduga Umur Perusahaan berpengaruh terhadap Underpricing.

\section{Pengaruh Inflasi terhadap Underpricing}

Kenaikan laju inflasi akanmeningkatkan harga barang dan jasa, yang akan meningkatkan biaya modal perusahaan sehinggaakan berpengaruh terhadap harga saham. Ketikainflasi tinggi, 
Saifudin dan Dia Rahmawati: Pengaruh Informasi Akuntansi Dan Non Akuntansi Terhadap Underpricing Ketika Initial Public Offering Di Bursa Efek Indonesia

harga barang akan naik, sehingga biayayang dikeluarkan perusahaan juga akan besar danitu berdampak pada laba yang diperoleh perusahaan.Dengan begitu, emiten akan cenderung menekanharga saham ketika IPO. Sebagian besar investorakan mengurangikegiatan investasinya karena faktor kenaikan hargabarang konsumsi. Jadi, tingginya inflasiakan meningkatkan undepricing saham perusahaanyang melakukan penawaran saham perdana.Mukti Lestari (2005) dalam Ratnasari dan Gunasti (2013) dalam penelitiannyamenghasilkan bahwa tingkat inflasi berpengaruhcukup signifikan terhadap fluktuasi harga sahamdalam time lag yang panjang. Maka diambil hipotesis sebagai berikut :

H4 : Diduga Inflasi berpengaruh terhadap Underpricing.

\section{Pengaruh ROE (Return on Equity) terhadap Underpricing.}

Nilai ROE yang semakin tinggi akan menunjukkan bahwa perusahaan mampu menghasilkan laba dimasa yang akan datang dan laba merupakan informasi penting bagi investor sebagai pertimbangan dalam menanamkan modalnya. Semakin besar nilai ROE maka mencerminkan resiko perusahaan IPO tersebut rendah, sehingga nilai ROE yang tinggi dapat mengurangi ketidakpastian saham dimasa mendatang serta menunjukkan tingkat keamanan investasi yang tinggi, yang berarti juga semakin rendah tingkat underpricingnya (Kurniawan, 2007 dalam Aini, 2013). Hal ini di dukung dengan penelitian yang dilakukan oleh Kurniawan (2007) dalam Aini (2013) yang menyatakan bahwa ROE berpengaruh secara signifikan terhadap underpricing. Maka diambil hipotesis sebagai berikut :

H5 : Diduga ROE berpengaruh terhadap Underpricing.

\section{Pengaruh DER (Debt to Equity Ratio) terhadap Underpricing.}

Nilai DER yang tinggi menandakan struktur permodalan usaha lebih banyak memanfaatkan hutang-hutang relatif terhadap ekuitas, sehingga menunjukan resiko financial atau resiko kegagalan perusahaan untuk mengembalikan pinjaman yang nantinya akan mempengaruhi tingkat return yang akan diterima oleh investor dimasa yang akan datang. Semakin tinggi nilai DER berarti semakin tinggi resiko saham emiten tersebut, maka semakin tinggi pula tingkat return yang diharapkan oleh investor, yang berarti juga semakin tinggi tingkat underpricingnya (Suyatmin, 2006 dalam Aini, 2013). Trisnaningsih (2005) dalam Aini (2013) menyatakan bahwa DER berpengaruh signifikan terhadap underpricing. Maka diambil hipotesis sebagai berikut :

H6 : Diduga DER berpengaruh terhadap Underpricing.

\section{Pengaruh Ukuran Perusahaan (size) terhadap Underpricing.}

Perusahaan berukuran besar umumnya memiliki tingkat ketidakpastian yang rendah dibandingkan dengan perusahaan kecil, karena dengan skala yang tinggi maka perusahaan besar cenderung tidak dipengaruhi oleh pasar, sebaliknya dapat mewarnai dan mempengaruhi keadaan pasar secara keseluruhan. Kejelasan informasi tentang perusahaan akan meningkatkan penilaian akan perusahaan, mengurangi tingkat ketidakpastian dan meminimalkan tingkat resiko dan underpricing (Sulistio, 2005 dalam Aini, 2013).Sandhiaji (2004) dan Islam (2007) dalam Aini (2013) menyatakan bahwa variabel ukuran perusahaan berpengaruh signifikan terhadap underpricing. Maka dapat diambil hipotesis sebagai berikut :

H7 : Diduga Ukuran Perusahaan berpengaruh terhadap Underpricing. 


\section{Pengaruh EPS (Earning per Share) terhadap Underpricing.}

Earning pershare menunjukkan kemampuan perusahaan untuk menghasilkan laba tiap lembar sahamnya. EPS dianggap sebagai alat ukur kinerja keuangan suatu perusahaan yang penting bagi manajemen dan investor. Dimana EPS yang besar menandakan kemampuan perusahaan yang lebih besar dalam menghasilkan keuntungan bersih dari setiap lembar saham. Peningkatan EPS menandakan perusahaan berhasil meningkatkan taraf kemakmuran investor untuk menambah jumlah modal yang ditanam pada perusahaan. Apabila perusahaan mampu meningkatkan laba untuk tiap lembar sahamnya,maka investor menganggap bahwa perusahaan dapat memberikan deviden perlembar saham yang besar. Hal ini menambah tingkat kepercayaan investor kepada perusahaan. Kepercayaan investor kepada emiten selalu dibarengi dengan permintaan akan saham emiten. Apabila permintaan saham naik maka harga sahampun meningkat.maka return saham akan meningkat. Retnowati (2013) menyatakan bahwa EPS mempunyai pengaruh yang signifikan terhadap underpricing. Maka diambil hipotesis sebagai berikut :

H8 : Diduga EPS berpengaruh terhadap Underpricing.

\section{METODE PENELITIAN}

\section{Populasi dan Sampel}

Populasi dalam penelitian ini adalah seluruh perusahaan yang melakukan penawaran saham perdana (IPO) pada tahun 2009 - 2013. Teknik pengambilan sampel dilakukan dengan purposive sampling dengan kriteria, sebagai berikut :

1. Melakukan penawaran saham perdana (IPO) di Bursa Efek Indonesia (BEI) tahun 2009 2013.

2. Initial return perusahaan pada saat melakukan penawaran saham perdana mengalami underpricing.

3. Data closing priceInitial Return diambil 15 hari setelah IPO.

4. Terdapat namaunderwriter (penjamin emisi) dan nama KAP yang mengaudit untuk dinilai secara dummy.

5. Data Laporan keuangan terakhir perusahaan yang melakukan penawaran saham perdana sebelum listing di BEI tahun 2009- 2013 lengkap dan tidak memiliki ROE negatif atau mengalami kerugian.

\section{Variabel dan Definisi Operasional Variabel}

Variabel Dependen dalam penelitian ini adalah Underpricing. Variabel independen dalam penelitian ini terdiri dari Reputasi Underwriter, Reputasi Auditor, Umur perusahaan, inflasi, ROE, DER, Ukuran perusahaan dan EPS.

\section{Underpricing}

Underpricing dalam penelitian ini dicerminkan oleh initial return yakni selisih harga saham atau keuntungan yang didapat pemegang saham karena perbedaan harga saham yang dibeli di pasar perdana dengan harga jual sahamyang bersangkutan di pasar sekunder hari pertama.Initial Return yang digunakan adalah dengan menghitung rata-rata nilai return selama 15 hari. Secara sistematis initial return dapat dirumuskan sebagai berikut (Anggita dan Gunasti, 2013) : 
Saifudin dan Dia Rahmawati: Pengaruh Informasi Akuntansi Dan Non Akuntansi Terhadap Underpricing Ketika Initial Public Offering Di Bursa Efek Indonesia

$$
U N D=\frac{\text { Harga Closing Pasar Sekunder }- \text { Harga IPO }}{\text { Harga IPO }}
$$

\section{Reputasi Underwriter}

Underwriter menurut Undang-Undang Pasar Modal No. 8 tahun 1995 adalah pihak yang membuat kontrak dengan Emiten untuk melakukan Penawaran Umum bagi kepentingan Emiten dengan atau tanpa kewajiban untuk membeli sisa Efek yang tidak terjual. Reputasi underwriter merupakan variabel dummy dengan memberikan nilai 1 untuk underwriter yang bereputasi tinggi serta nilai 0 untuk sebaliknya. Standar pengukuran reputasi underwriter yang bereputasi tinggi berdasarkan perangkingan yang terdapat di IDX Fact Book berdasarkan big five total value underwriter (Sulistio, 2005).

\section{Reputasi Auditor}

Auditor berfungsi melakukan pemeriksaan terhadap laporan keuangan perusahaan yang akan melakukan go public. Reputasi auditor merupakan variabel dummy dengan memberikan nilai 1 untuk auditor yang prestigious serta nilai 0 untuk sebaliknya. Standar pengukuran reputasi auditor yang prestigious berdasarkan KAP yang menjadi partner dari auditor The Big Four (Sulistio, 2005).

\section{Umur Perusahaan}

Umur perusahaan menunjukkan seberapa lama perusahaan mampu bertahan dan menjadi bukti perusahaan mampu bersaing dan dapat mengambil kesempatan bisnis yang ada dalam perekonomian. Variabel umur perusahaan diukur dengan lamanya perusahaan beroperasi yaitu sejak perusahaan itu didirikan (established date) berdasarkan akta pendirian sampai dengan saat perusahaan melakukan IPO (listing date) (Amelia, 2007).

\section{Inflasi}

Inflasi adalah suatu keadaan dimana terjadi meningkatnya harga-harga atau suatu keadaan dimana terjadinya penurunan daripada nilai uang yang beredar di masyarakat.Tingkat inflasi yang digunakan dalam penelitian ini adalah tingkat inflasi yang ditetapkan oleh Bank Sentral satu bulan sebelum emiten melakukan IPO.

\section{ROE (Return on Equity)}

ROE merupakan ukuran profitabilitas yang memberikan informasi kepada para investor tentang seberapa besar tingkat pengembalian modal investor dari perusahaan yang berasal dari kinerja perusahaan dalammenghasilkan laba. ROE dapat dihitung dengan rumus sebagai berikut :

$$
\mathrm{ROE}=\frac{\text { Laba Bersih Setelah Pajak }}{\text { Modal Saham }}
$$

\section{DER (Debt to Equity Ratio)}

DER yakni kemampuan perusahaan dalam memenuhi seluruh kewajibannya yang ditunjukkan oleh beberapa bagian modal sendiri yang digunakan untuk membayar hutang (Kurniawan, 2007 dalam Aini, 2013). DER dihitung dengan rumus sebagai berikut : 


$$
\mathrm{DER}=\frac{\text { Total Liabilities }}{\text { Total Equity }}
$$

\section{Ukuran Perusahaan (size)}

Ukuran perusahaan merupakan cerminan potensi perusahaan dalam menghasilkan arus kas dan kemampuan untuk mengakses informasi yang lebih besar.Variabel ukuran perusahaan diukur dengan menghitung log natural total aktiva tahun terakhir sebelum perusahaan tersebut listing (Suyatmin, 2006 dalam Aini, 2013).

\section{EPS (Earning per Share)}

EPS (Earning Per Share) merupakan rasio yang mengukur seberapa besar dividen per lembar saham yang akan dibagikan kepada investor setelah dikurangi dengan dividen bagi para pemilik perusahaan. Earning Per Share dapat diukur dengan rumus :

$$
\text { EPS }=\frac{\text { Net Income After Tax }}{\text { Jumlah Lembar Saham yang Beredar }}
$$

\section{HASIL DAN PEMBAHASAN}

Berdasarkan teknik pengambilan sampel, kriteria yang digunakan dalam penelitian ini adalah semua perusahaan yang melakukan IPO yang mengalami underpricing periode 20092013, closing price initial return diambil 15 hari setelah IPO, tidak mengalami ROE negatif dan terdapat nama KAP dan penjamin emisinya. Data yang diperoleh dari BEI, terdapat 116 perusahaan yang melakukan IPO tahun 2009-2013, dari jumlah tersebut sebanyak 25 perusahaan tidak dimasukkan kedalam sampel karena tidak mengalami underpricing, 13 perusahaan memiliki ROE negative dan data laporan keuangannya tidak lengkap dan 15 data outlier karena range yang terlalu tinggi. Setelah beberapa eliminasi, sampel akhir yang digunakan dalam penelitian ini berjumlah 60 perusahaan.

\section{Tabel 1. Statistik Deskriptif}

\begin{tabular}{lrrrrr}
\hline \multicolumn{1}{c}{ Variabel } & N & Minimum & Maximum & Mean & $\begin{array}{c}\text { Std. } \\
\text { Deviation }\end{array}$ \\
\hline UND & 60 & .01 & .70 & .2142 & .18366 \\
DER & 60 & .06 & 14.10 & 2.8592 & 2.88942 \\
EPS & 60 & 1.63 & 726.00 & 76.1655 & 126.58801 \\
ROE & 60 & .33 & 194.76 & 28.5745 & 32.35625 \\
AGE & 60 & 1 & 59 & 20.25 & 14.710 \\
INF & 60 & -.35 & 1.57 & .3793 & .43235 \\
AUD & 60 & 0 & 1 & .42 & .497 \\
UNDW & 60 & 0 & 1 & .45 & .502 \\
SIZE & 60 & 10.01 & 17.62 & 14.0459 & 1.46987 \\
\hline Valid N & 60 & & & & \\
(listwise) & & & & & \\
\hline
\end{tabular}


Saifudin dan Dia Rahmawati: Pengaruh Informasi Akuntansi Dan Non Akuntansi Terhadap Underpricing Ketika Initial Public Offering Di Bursa Efek Indonesia

Berdasarkan uji deskriptif yang terdapat dalam tabel 1 nampak bahwa nilai rata-rata underpricingnya sebesar $21,42 \%$ dengan standar deviasi 18,36\%. Tingkat underpricing terendah sebesar $1 \%$ terjadi pada PT Dharma Satya Nusantara Tbk (DSNG) yang melakukan IPO pada tanggal 4 Juni 2013 sebanyak 275.000.000 dengan nilai nominal Rp. 100,- per saham dengan harga penawaran Rp. 1.850,- per saham. Total aktiva DSNG sebesar Rp.5.921.055, menggunakan KAP dan underwriter bereputasi tinggi, yaitu Siddharta \& Widjaja dan PT. Ciptadana Securities.

Tingkat underpricing tertinggi sebesar $70 \%$ terjadi pada Bank Sinarmas, Tbk (BSIM) yang melakukan IPO pada tanggal 3 Desember 2010 dengan penjamin emisi efek PT. Sinarmas Sekuritas dengan jumlah saham yang ditawarkan sebanyak 1.600.000.000 lembar dengan nilai nominal Rp. 100,- dan harga penawaran Rp. 150,- per saham.

DER selama periode pengamatan nilai minimumnya sebesar 0.06 yang terjadi pada PT Minna Padi Investama Tbk (PADI) dan nilai maksimum sebesar 14.10 pada PT Sarana Meditama Metropolitan Tbk (SAME). Ditinjau dari profitabilitas (ROE) selama periode pengamatan, ROE minimum sebesar 0.33 yaitu oleh PT.Visi Media Asia Tbk (VIVA) dan nilai maksimum 194.76 oleh PT. Toba Bara Sejahtera Tbk (TOBA). EPS selama periode pengamatan mempunyai nilai rata-rata sebesar 76.1655 dengan standar deviasi 126.58801.Nilai minimum sebesar 1.63 yaitu oleh PT. Midi Utama Indonesi Tbk (MIDI) dan nilai maksimum sebesar 726 oleh PT. Sawit Sumbermas Sarana Tbk (SSMS). Umur perusahaan yang minimum diperoleh selama periode pengamatan adalah 1 tahun yaitu PT. Indofood CBP Sukses Makmur Tbk (ICBP)yang melaksanakan IPO pada tahun 2010 dan nilai maksimum 59 tahun yaitu pada PT. Bank Tabungan Negara, Tbk (BBTN).

Inflasi selama periode pengamatan mempunyai nilai rata-rata sebesar 0.3793 dengan standar deviasi sebesar 0.43235 .Nilai minimum -0.35 dan nilai maksimum 1.57. Interpretasi variabel dummy berdasarkan statistik deskriptif, mempunyai nilai rata-rata reputasi auditor sebesar 0.42 berarti $42 \%$ dari total sampel menggunakan auditor yang prestigious (Big 4) sedangkan sisanya sebesar 58\% menggunakan auditor yang tidak prestigious.

Nilai rata-rata reputasi underwritersebesar 0.45 yang berarti $45 \%$ dari total sampel menggunakan jasa reputasi underwriter yang bereputasi tinggi, sedangkan sisanya sebesar 55\% menggunakan reputasi underwriter yang bereputasi rendah. Ukuran perusahaan yang minimum diperoleh yang diukur menggunakan Logaritma natural (Ln) dari nilai total aktiva adalah sebesar 10.01 Ln total aktiva atau nilai total aktiva sebesar Rp. 22.185.000.000 yaitu pada PT. Skybee Tbk (SKYB)dan nilai maksimum sebesar 17.62 Ln Total aktiva atau nilai total aktiva sebesar Rp. 32.410.329.000.000 pada PT. Bank Pembangunan Daerah Jawa Barat (BJBR).

Berdasarkan tabel 2, nilai signifikansi dari hasil uji statistik sebesar 0,000 yang lebih kecil dari 0,05, maka dapat dinyatakan bahwa variabel reputasi underwriterberpengaruh signifikan terhadap underpricing. Hal ini berarti H1 yang menyatakan reputasi underwiter berpengaruh signifikan pada underpricing, diterima.

Hasil penelitian ini konsisten dengan penelitian sebelumnya yang dilakukan oleh Kristiantari (2012), Junaeni dan Agustian (2013), dan Ratnasari dan Hudiwinarsih (2013), bahwa reputasi underwriter berpengaruh signifikan terhadap tingkat underpricing.Penelitian ini menunjukkan bahwa underwriter yang bereputasi tinggi lebih berani memberikan harga yang tinggi sebagai konsekuensi dari kualitas penjaminannya, sehingga tingkat underpricing rendah.Dalam menghadapi IPO, calon investor cenderung melihat terlebih dahulu pihak yang menjadi underwriter karena menurut investor, underwriter dianggap memiliki informasi yang 
lebih lengkap tentang kondisi emiten.Begitu pula jika dibandingkan dengan emiten, underwriter dianggap memiliki informasi yang lebih lengkap tentang pasar.

Tabel 2. Hasil Pengujian Regresi Linier Berganda

\begin{tabular}{|c|c|c|c|c|c|}
\hline \multirow[t]{2}{*}{ Model } & \multicolumn{2}{|c|}{$\begin{array}{l}\text { Unstandardized } \\
\text { Coefficients }\end{array}$} & \multirow{2}{*}{$\begin{array}{c}\text { Standardized } \\
\text { Coefficients } \\
\text { Beta }\end{array}$} & \multirow[t]{2}{*}{$\mathbf{t}$} & \multirow[t]{2}{*}{ Sig } \\
\hline & $\mathrm{B}$ & Std. Error & & & \\
\hline (Constant) & .720 & .091 & & 7.918 & .000 \\
\hline DER & .069 & .027 & .323 & 2.565 & .013 \\
\hline EPS & .001 & .001 & .202 & 1.792 & .079 \\
\hline $\mathrm{ROE}$ & -.002 & .005 & -.047 & -.453 & .652 \\
\hline AGE & -.006 & .002 & -.247 & -2.452 & .017 \\
\hline INF & -.352 & .077 & -.420 & -4.550 & .000 \\
\hline AUD & -.502 & .072 & -.699 & -6.947 & .000 \\
\hline UNDW & .286 & .067 & .402 & 4.280 & .000 \\
\hline SIZE & -.025 & .000 & -.090 & -.767 & .447 \\
\hline
\end{tabular}

Berdasarkan nilai signifikansi dari hasil uji statistik sebesar 0,000 yang lebih kecil dari 0,05, maka dapat dinyatakan bahwa variabel Reputasi Auditor berpengaruh signifikan terhadap underpricing. Hal ini berarti $\mathrm{H} 2$ yang menyatakan Reputasi Auditor berpengaruh signifikanterhadap underpricing, diterima.

Berpengaruhnya variabel reputasi auditor dalam penelitian ini mungkin dikarenakan sebagian besar perusahaan yang IPO menggunakan jasa reputasi auditor yang prestigious. Investor menganggap bahwa kualitas auditor mempengaruhi hasil audit laporan keuangan perusahaan dan percaya terhadap auditor yang mempunyai reputasi tinggi dalam mengaudit laporan akan memberikan informasi yang sesungguhnya tentang keadaan keuangan perusahaan.

Hasil penelitian ini konsisten dengan penelitian yang dilakukan Aini (2013), Anggita dan Gunasti (2013) bahwa reputasi auditor berpengaruh terhadap tingkat underpricing. Variabel reputasi auditor berhubungan negatif dengan tingkat underpricing yang artinya semakin tinggi reputasi auditor maka akan semakin rendah tingkat underpricing. Perusahaan yang IPO dan menggunakan KAP yang bereputasi tinggi atau KAP yang berafiliasi Big Four akan memberikan signal positif bagi perusahaan yang akan membuat investor semakin percaya dengan kualitas laporan audit. Hasil ini didukung dengan teori Titman dan Trueman (1986) dalam Anggita dan Gunasti (2013) yang menyajikan signaling model dengan pernyataan bahwa auditor yang memiliki kualitas menghasilkan informasi yang berguna bagi investor didalam menaksir nilai perusahaan yang melakukan IPO.

Berdasarkan nilai signifikansi dari hasil uji statistik sebesar 0,017 yang lebih kecil dari 0,05, maka dapat dinyatakan bahwa variabel Umur Perusahaan berpengaruh signifikan terhadap underpricing. Hal ini berarti H3 yang menyatakan Umur Perusahaan berpengaruh signifikan pada underpricing, diterima.

Hasil penelitian ini sejalan dengan penelitian yang dilakukan oleh Sandhiaji (2004) yang menyatakan bahwa umur perusahaan berpengaruh terhadap underpricing. Umur perusahaan menunjukkan seberapa lama perusahaan tersebut berdiri dan beroperasi. Lama berdirinya suatu perusahaan dipersepsikan sebagai perusahaan yang sudah tahan uji sehingga kadar resikonya rendah dan bisa menarik investor karena diyakini perusahaan yang sudah lama berdiri bisa dikatakan lebih berpengalaman dalam menghasilkan return bagi perusahaan yang pada akhirnya 
Saifudin dan Dia Rahmawati: Pengaruh Informasi Akuntansi Dan Non Akuntansi Terhadap Underpricing Ketika Initial Public Offering Di Bursa Efek Indonesia

berdampak pada meningkatnya return yang diterima oleh investor dalam jangka panjang. Sehingga perusahaan yang telah lama berdiri akan mengurangi tingkat underpricing (Suyatmin, 2006 dalam Aini, 2013).

Berdasarkan nilai signifikansi dari hasil uji statistik sebesar 0,000 yang lebih kecil dari 0.05, maka dapat dinyatakan bahwa variabel Inflasi berpengaruh signifikan terhadap underpricing. Hal ini berarti $\mathrm{H} 4$ yang menyatakan Inflasi berpengaruh signifikan pada underpricing, diterima.Nilai signifikansi sebesar 0.000 menunjukkan bahwa inflasi yang rendah mempengaruhi harga saham. Ketika inflasi tinggi, harga akan naik dan akan berdampak pada laba yang diperoleh perusahaan,

Hasil penelitian ini membuktikan bahwa terdapat pengaruh yang signifikan terhadap inflasi yang menggunakan closing price sehari dengan 15 hari setelah IPO.Penelitian ini didukung oleh Lestari (2005) yang dalam penelitiannya menyatakan bahwa tingkat inflasi berpengaruh cukup signifikan terhadap fluktuasi harga saham dalam time lag yang panjang. Kenaikan laju inflasi berpengaruh dalam peningkatan harga barang dan jasa yang tentunya akan meningkatkan biaya modal perusahaan sehingga akan berpengaruh terhadap harga saham. Perusahaan akan cenderung menekan harga saham ketika IPO yang tentunya akan menyebabkan underpricing.

Berdasarkan nilai signifikansi dari hasil uji statistik sebesar 0,652 yang lebih besar dari 0,05, maka dapat dinyatakan bahwa variabel ROE tidak berpengaruh signifikan terhadap underpricing. Hal ini berarti $\mathrm{H} 5$ yang menyatakan ROE berpengaruh signifikan pada underpricing, ditolak.

Hasil ROE yang tidak signifikan dalam penelitian ini dimungkinkan karena kemampuan setiap industri dalam menghasilkan laba yang tinggi berbeda-beda, seperti yang diungkapkan oleh Syahputra (2008) misalnya industri tambang yang merupakan industri tambang cenderung sulit menghasilkan laba yang tinggi setiap tahun karena jenis investasinya yang jangka panjang berbeda dengan industri manufaktur atau perbankan yang jenis investasinya jangka pendek dan menengah.

Hasil penelitian ini sejalan dengan penelitian yang dilakukan oleh Syahputra (2008) dan Nur Aini (2013) yang menyatakan bahwa ROE tidak berpengaruh terhadap underpricing. Syahputra (2008) mengatakan tidak berpengaruhnya ROE terhadap underpricing didugakarena beberapa hal, diantaranya adalah kemampuan setiap industri dalam menghasilkan laba yang tinggi berbeda-beda,misalnya industri tambang yang merupakan industri tambang cenderung sulit menghasilkan laba yang tinggi setiap tahun karena jenis investasinya yang jangka panjang berbeda dengan industri manufaktur atau perbankan yang jenis investasinya jangka pendek dan menengah.Alasan lain kenapa ROE tidak berpengaruh adalah tujuan pembelian saham adalah untuk tujuan spekulasi bukan investasi,bagi spekulan ROE tidaklah begitu penting karena saham yang mereka beli tidak akan ditahan dalam waktu lama.

Berdasarkan nilai signifikansi dari hasil uji statistik sebesar 0.013 yang kurang dari 0.05 , maka dapat dinyatakan bahwa variabel DER berpengaruh signifikan terhadap underpricing.Hal ini berarti H6 yang menyatakan DER berpengaruh signifikan pada underpricing, diterima.

Hasil penelitin ini sejalan dengan penelitian sebelumnya yang dilakukan oleh Wahyusari (2013) yang menyatakan bahwa DER berpengaruh signifikan terhadap underpricing pada perusahaan yang IPO. DER yang tinggi menunjukan resiko kegagalan finansial atau kegagalan pembayaran utang terhadap kreditor yang semakin tinggi.Perusahaan dengan nilai DER yang tinggi akancenderung menggunakan hasil IPO untuk membayar utang pada kreditur daripada untuk melakukan perluasan usaha dalam rangka mengembangkan perusahaannya. Hal tersebut 
dapat mengurangi minat investor sehingga dalam melakukan keputusan investasi akan mempertimbangkan nilai DER yang tinggi, oleh karena itu tingkat ketidakpastiannya semakin tinggi dan menyebabkan tingkat underpricing semakin tinggi.

Berdasarkan nilai signifikansi dari hasil uji statistik sebesar 0,447 yang lebih besar dari 0,05, maka dapat dinyatakan bahwa variabel Ukuran Perusahaan tidak berpengaruh signifikan terhadap underpricing. Hal ini berarti H7 yang menyatakan Ukuran Perusahaan berpengaruh signifikanterhadapunderpricing, ditolak. Tidak signifikannya variabel ukuran perusahaan dalam penelitian ini mungkin disebabkan karena aset perusahaan bukan merupakan faktor utama yang dijadikan pertimbangan oleh investor dalam menilai perusahaan. Terbukti dengan nilai aset yang rendah dibandingkan dengan perusahaan lain yaitu sebesar Rp. 22.185.000.000 yang dimiliki oleh PT.Skybee Tbk (SKYB), perusahaan tetap mampu mempertahankan kinerjanya yang dapat dilihat dengan nilai ROE yang tidak rendah yaitu sebesar $18.97 \%$.

Hasil penelitian ini konsisten dengan penelitian yang dilakukan oleh Nur Aini (2013) bahwa ukuran perusahaan tidak berpengaruh terhadap underpricing. Hal ini disebabkan karena investor lebih menilai kinerja perusahaan yang dianggap lebih penting daripada ukuran perusahaannya. Perusahaan yang kecil tetap mampu menjaga tingkat laba yang sama dengan perusahaan besar karena keduanya memiliki perbedaan kompetensi dalam menyelamatkan perusahaan saat mengalami masalahkeuangan. Baik perusahaan yang memiliki ukuran besar atau kecil akan berusaha dalam penghematan biaya. Hal tersebut karena perusahaan berupaya untuk meningkatkan profit demi menjaga kelangsungan usaha. Kinerja perusahaan pada dasarnya merupakan hasil yang dicapai suatu perusahaan dengan mengelola sumber daya yang ada dalam perusahaan dengan seefektif dan seefisien mungkin guna mencapai tujuan yang telah ditetapkan manajemen (Hernandiastoro, (2005) dalam Nur Aini (2013).

Berdasarkan nilai signifikansi dari hasil uji statistik sebesar 0,079 yang lebih besar dari 0,05, maka dapat dinyatakan bahwa variabel EPS berpengaruh positif dan tidak signifikan terhadap underpricing. Hal ini berarti H8 yang menyatakan EPS berpengaruh signifikan pada underpricing, ditolak. Tidak berpengaruhnya variabel EPS terhadap underpricing dikarenakan rasio ini tidak dapat memberikan ekspektasi kepada investor mengenai kenaikan ataupun penurunan harga saham suatu perusahaan untuk memperoleh pengembalian terhadap investasi yang diberikan.

Hasil penelitian ini konsisten dengan penelitian yang dilakukan Helen (2005), Yuli Astuti dan Syahyunan (2012) bahwa EPS berpengaruh tidak signifikan terhadap underpricing. Menurut Hanafi dan Halim (2007) EPS dinilai tidak konsisten untuk pengukuran profitabilitas karena memakai laba perusahaan pada numerator (yang dibagi) tetapi memakai jumlah saham pada pembagi (denominator) yang merupakan hasil keputusan pendanaan.Perusahaan bisa mengalami laba yang menurun tetapi kalau perusahaan tersebut mengurangi jumlah saham yang beredar (misalkan dengan melakukan pembelian saham kembali/treasury stock), EPS yang dihasilkan bisa tetap tinggi.Sehingga EPS tidak dapat memberikan ekspektasi kepada investor mengenai kenaikan ataupun penurunan harga saham suatu perusahaan untuk memperoleh pengembalian terhadap investasi yang diberikan.Oleh karena itu investor mungkin kurang memperhatikan nilai EPS untuk keputusan investasi.

\section{SIMPULAN}

Dari penelitian tersebut diatas, maka simpulan yang dapat diambil bahwa terdapat pengaruh Debt Equity Ratio (DER), umur perusahaan (age), reputasi underwriter , reputasi auditor dan inflasi terhadap underpricing. Tidak terdapat pengaruh Earning Per Share (EPS), Return On Equity (ROE), ukuran perusahaan (size), dan terhadap underpricing. 
Saifudin dan Dia Rahmawati: Pengaruh Informasi Akuntansi Dan Non Akuntansi Terhadap Underpricing Ketika Initial Public Offering Di Bursa Efek Indonesia

Keterbatasan dalam penelitian ini adalah nilai Koefisien Determinasi yang rendah yaitu hanya 52.8\% yang berarti variabel dependen dapat dijelaskan oleh variabel independen sebesar 52.8\% sisanya $47.2 \%$ dipengaruhi faktor lain diluar penelitian ini. Misalnya Price Earning Share (PER), Prosentase Penawaran Saham, Return On Asset (ROA) atau Kondisi Pasar. Agenda penelitian yang akan datang dapat menggunakan variabel Price Earning Share (PER), Prosentase Penawaran Saham, Return On Asset (ROA) atau Kondisi Pasar.

\section{DAFTAR PUSTAKA}

Aini, Shofiyah Nur. 2013. Faktor-Faktor yang Mempengaruhi Underpricing Saham pada Perusahaan IPO di BEI Periode 2007-2011. Jurnal Ilmiah Manajemen. 1(1).

Darmadji, Tjiptono dan Hendy M.Fakhruddi. 2011. Pasar Modal di Indonesia. Jakarta: Salemba Empat.

Ghoali, Imam. 2011. Aplikasi Analisis Multivariate dengan Program IBM SPSS 19. Semarang: Badan Penerbit Universitas Diponegoro.

Handayani, Sri Retno. 2008. Analisis Faktor-faktor yang Mempengaruhi Underpricing pada Penawaran Umum Perdana (Studi Kasus pada Perusahaan Keuangan yang Go Publik di Bursa Efek Jakarta Tahun 2000-2006). Tesis. Semarang: Magister Manajemen Universitas Diponegoro.

Ikhsan, Adhisyahfitri Evalina, M. Nur Yahya dan Saidaturrahmi. 2012. Peringkat Obligasi dan Faktor yang Mempengaruhinya. Pekbis Jurnal. 4(2).

Jama'an. 2008. Teori Sinyal. Available at: http://ekonomi.kabo.biz/2011/07/teori-sinyal.html

Jogiyanto.2010. Teori Portofolio dan Analisis Investasi. Yogyakarta: BPFE UGM.

Junaeni, Irawati dan Rendi Agustian. 2013. Analisis Faktor-Faktor yang Mempengaruhi Tingkat Underpricing Saham Pada Perusahaan yang Melakukan Initial Public Offering di BEI. ISSN. 1 (1).

Kompas.com. 2010. Rekayasa IPO Krakatau Steel. Available at: (http://bisniskeuangan.kompas.com/read/2010/11/11/08132823/Rekayasa.IPO.Krakatau.S teel). 19 Oktober 2014.

Kristiantari, I Dewa Ayu. 2012. Analisis Faktor-Faktor yang Mempengaruhi Underpricing Saham Pada Penawaran Saham Perdana di BEI. Tesis. Bali: Magister Akuntansi Fakultas Ekonomi Universitas Udayana.

Ratnasari, Anggita dan Gunasti Hudiwinarsih. 2013. Analisis Pengaruh Informasi Keuangan, Non Keuangan serta Ekonomi Makro terhadap Underpricing pada Perusahaan ketika IPO, Jurnal Buletin Studi Ekonomi. 18 (2).

Retnowati, Eka. 2013. Penyebab Underpricing pada Penawaran Saham Perdana di Indonesia, Jurnal Akuntansi. 2(2).

Rusmanto, Toto dan Agnesia Fransisca. 2012. Pengaruh Pemilihan Metode Akuntansi, Auditor, Underwriter, dan Kepemilikan terhadap Tingkat Underpricing Saham. ISSN. 11(2).

Safitri, Tety Anggita. 2013. Asimetri Informasi dan Underpricing. Jurnal Dinamika Manajemen. 4 (1).

Sandhiaji, Bram Nugroho. 2004. Analisis Faktor-Faktor yang MempengaruhiUnderpricing pada Penawaran Umum Perdana (IPO) Periode Tahun 1996-2002. Tesis. Semarang: Magister Akuntansi Fakultas Ekonomi Universitas Diponegoro,

Sp.beritasatu.com. 2011. BEI: Jumlah IPO di 2011 Terbanyak dalam 10 Tahun Terakhir. Available at: (http//sp.beritasatu.com/ekonomidanbisnis/bei-jumlah-ipo-di-2011terbanyak-dalam-10-tahun-terakhir/15398). 19 Oktober 2014. 
Sulistio, Helen. 2005. Pengaruh Informasi Akuntansi dan Non Akuntansi Terhadap Initial Return :Studi pada Perusahaan yang Melakukan Initial Public Offering di Bursa Efek Jakarta. Prosiding. Disajikan Dalam Simposium National Akuntansi VIII.

Wahyusari, Ayu. 2013. Analisis Faktor-Faktor yang Mempengaruhi Underpricing Saham Saat IPO di BEI. Jurnal Akuntansi. 4(2).

Wolk et.al. 2001. Teori Sinyal, http://ekonomi.kabo.biz/2011/07/teori-sinyal.html

Yolana, Chastina dan Dwi Martani. 2005. Variabel-Variabel yang Mempengaruhi fenomena Underpricing pada Penawaran Saham Perdana di BEJ Tahun 1994-2001. Prosiding. Disajikan Dalam Simposium Nasional Akuntansi VIII, Solo, 15 - 16 September.

Zuhafni, 2014. Analisis Faktor-Faktor yang Berpengaruh terhadap Underpricing dalam Initial Public Offering (IPO) pada Kelompok Perusahaan Keuangan dan Non Keuangan di Bursa Efek Jakarta (BEJ). Jurnal Apresiasi Ekonomi. 2(1).

http://bps.go.id

http://www.e-bursa.com

http://www.idx.co.id

http://www.yahoofinance.com 